\title{
GENETIC ANALYSIS FOR CONSERVATION OF AUSTROPOTAMOBIUS ITALICUS POPULATIONS IN MARCHES REGION (CENTRAL ITALY)
}

\author{
R. CATAUDELLA (1), N. PUILLANDRE (2), F. GRANDJEAN (2)
}

(1) Istituto di Scienze Morfologiche, Università di Urbino "Carlo Bo", Campus scientifico, Località Crocicchia, I-61029 Urbino PU, Italy.

E-Mail: s.cataudella@uniurb.it

(2) Laboratoire de Génétique et Biologie des Populations de Crustacés, UMR 6556, Université de Poitiers, 40, avenue du Recteur Pineau, F-86022 Poitiers cedex, France.

Reçu le 20 juillet 2006

Accepté le 30 janvier 2006

Received July 20, 2006

Accepted January 30, 2006

\begin{abstract}
The genetic characteristics of white-clawed crayfish populations in Marches Region (Central Italy) was investigated to plan conservation strategies. In order to clarify their taxonomic status, 50 specimens from ten populations were collected in six different hydrographic drainages of the Umbro-Marchigiano Appennine. The genetic relationships of the Austropotamobius italicus specimens were assessed using DNA sequences of the mitochondrial DNA 16S rRNA gene.The 3 distinct haplotypes M1, M2, M3 detected have been compared to those available in GenBank corresponding to four subspecies described for $A$. italicus. Our results confirmed the presence of both subspecies $A$. $i$. carsicus (M1 \& M2) and A. i. meridionalis (M3) in Marches region. Two mixed populations with both subspecies have been characterized. These new data of the genetic structure of population will be used to plan management and recovery programs.
\end{abstract}

Key-words: Austropotamobius italicus, subspecies, taxonomy, conservation.

\section{ANALYSES GÉNÉTIQUES POUR LA CONSERVATION DES POPULATIONS D'AUSTROPOTAMOBIUS ITALICUS DANS LA RÉGION DES MARCHES (ITALIE CENTRALE)}

\section{RÉSUMÉ}

Les caractéristiques génétiques des populations d'écrevisses à pattes blanches de la région des Marches (Italie centrale) ont été étudiées dans le but de définir une stratégie de conservation. 50 individus provenant de 10 populations appartenant à six bassins hydrographiques des Apennins, de l'Ombrie et des Marches ont été prélevés dans le but de déterminer leurs statuts taxonomiques. Les relations génétiques entre individus d'Austropotamobius italicus ont été appréhendées par sequençage d'une portion du gène d'ADN mitochondrial codant pour l'ARN ribosomique 16S. Les trois haplotypes obtenus, $M 1, M 2$ et $M 3$, ont été comparés à ceux mis en ligne dans GenBank correspondant aux quatre sous-espèces décrites chez $A$. italicus. Nos résultats confirment la présence dans la région des deux sous-espèces $A$. $i$. carsicus (M1 \& M2) et $A$. $i$. meridionalis (M3). Deux populations mixtes ont été caractérisées. Ces nouvelles données sur la structure 
génétique des populations seront utilisées pour définir des plans de gestion et pour mettre en œuvre des programmes de repeuplement.

Mots-clés: Austropotamobius italicus, sous-espèces, taxonomie, conservation.

\section{INTRODUCTION}

The white-clawed crayfish, Austropotamobius pallipes complex, is widespread throughout Europe and its range has been drastically restricted $(\mathrm{HOLDICH}, 2002)$ due to a combination of several factors affecting the habitat quality or the health of populations (FÜREDER et al., 2003). To protect the existing populations, numerous conservation plans thoughout Europe have emerged during the last 10 years, often including genetic analysis of populations to help management decisions. These studies have revealed a high genetic structure among European populations and more particularly among Italian ones (SANTUCCl et al, 1997; LÖRTSCHER, 1998; GRANDJEAN et al., 2000; LARGIADER et al., 2000, FRATINI et al., 2005, TRONTELJ et al., 2005; ZACCARA et al., 2004 and 2005). These authors reported the presence of two well differentiated groups in Europe corresponding to pallipes and italicus specimens. Although discussions on the status of these two groups are still in progress, separate species status for pallipes and italicus was originally proposed by GRANDJEAN et al. (2002) and accumulating evidence favours that interpretation. Within italicus species, these studies showed a strong genetic structure with the presence of four differentiated groups (FRATINI et al., 2005): A. i. italicus in the TuscanEmilian Apennine (i.e. central Italy); $A$. i. carsicus in North-eastern Italy; $A$. i. carinthiacus in Central and and North-western Italy and $A$. $i$. meridionalis corresponding to specimens from Latium, Abruzzi, and Southern Italy and also including Slovenian specimens. However, if we take in account the extremely close genetic relationship between $A$. $i$. italicus and carinthiacus, it seems to be more reliable to cluster these two subspecies into one A. p. italicus as proposed by Machino in HOLDICH (2002). Actually Austropotamobius italicus is not an official recognised taxon, but the complex phylogenetic structure of the Austropotamobius pallipes supports the necessity of a systematic revision.

The aim of the present study was to investigate the genetic relationships among appennine populations by the analysis of sequences of $16 \mathrm{~S}$ RNA gene to determine the subspecific status of specimens. This preliminary study on the genetic characteristics of populations in Marches Region will be used to plan management and recovery programs.

\section{MATERIALS AND METHODS}

We collected 50 specimens (five specimens from each population) by hand from ten different rivers of the Umbria-Marches Appennine in six hydrographic drainages of the Adriatic sea (Figure 1). One pereopod was taken per individual and was put in absolute ethanol. Tissues were dehydrated $(2 \mathrm{~min})$ in sterile water and ground with plastic pestles in microcentrifuge tubes containing $100 \mathrm{mM}$ Tris, $10 \mathrm{mM}$ EDTA, $100 \mathrm{mM} \mathrm{NaCl}, 0.1 \%$ SDS, $50 \mathrm{mM} \mathrm{DTT}$ and $10 \mu \mathrm{l} / \mathrm{ml}$ proteinase $\mathrm{K}(\mathrm{pH}=8)$. Samples were incubated at $37^{\circ} \mathrm{C}$ for 4 hours and DNA extracted twice with phenol/chloroform/isoamyl alcohol (25: 24:1) followed by an additional extraction with chloroform. The DNA was then precipitated with one volume of isopropanol and $1 / 10$ volume of $3 \mathrm{M}(\mathrm{pH}=5.2)$ sodium acetate. It was then dried and resuspended in sterile water. DNA was collected by centrifugation, dried and diluted in water to a final concentration of $20 \mathrm{ng} / \mu \mathrm{l}$.

Polymerase chain reaction (PCR) amplification of of a rDNA 16S portion about 500 base pairs (bp) long was carried out in a Progene thermocycler using primers available in GRANDJEAN et al. (2002). 


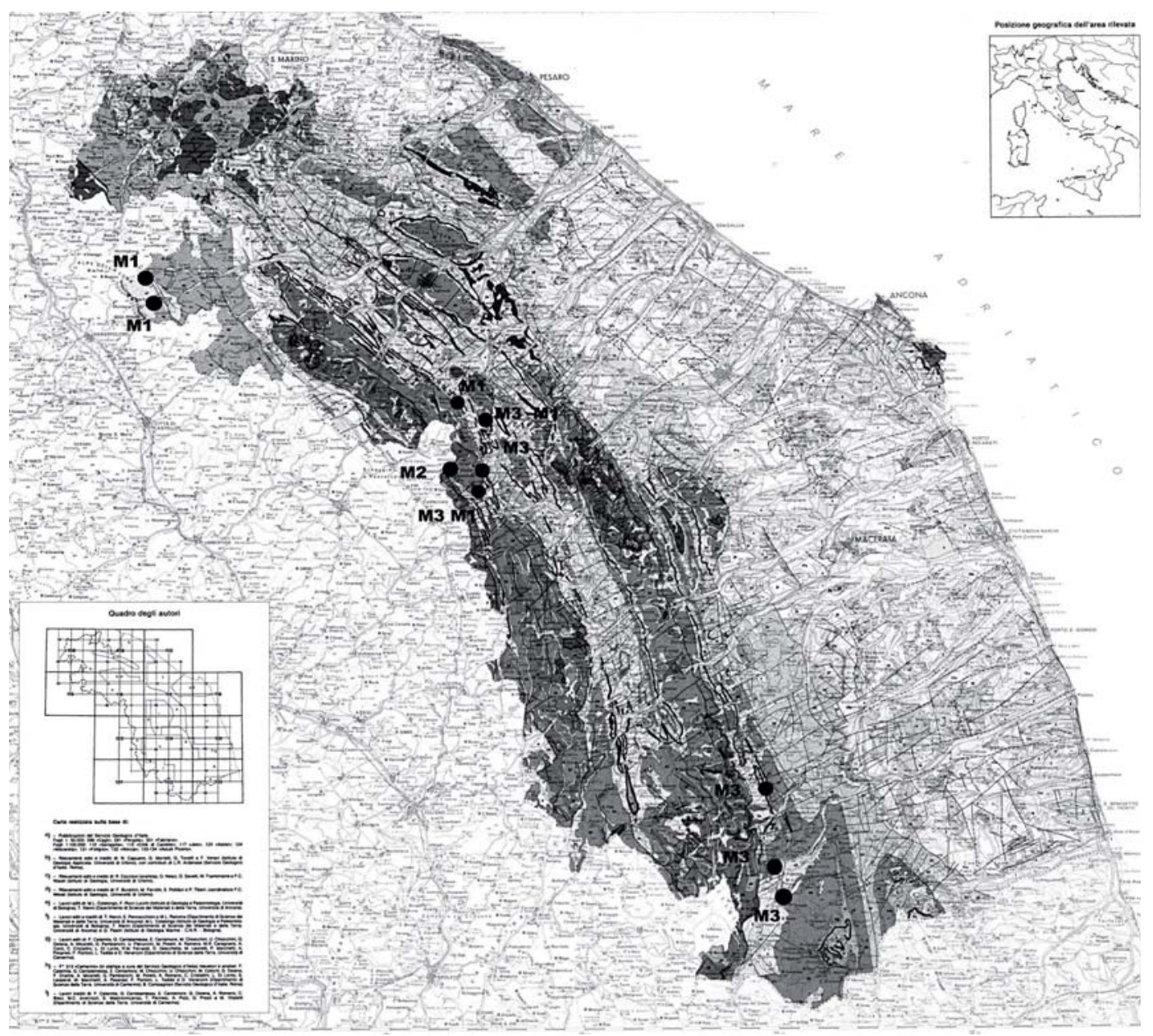

\section{Figure 1}

Geographical distribution of haplotypes of Austropotamobius italicus subspecies in Marches region.

\section{Figure 1}

Distribution géographique des haplotypes des sous-espèces de Austropotamobius italicus dans la région des Marches.

The optimal cycling program was $2 \mathrm{~min}$ at $94^{\circ} \mathrm{C}, 1 \mathrm{~min}$ at $35^{\circ} \mathrm{C}, 2 \mathrm{~min}$ at $72^{\circ} \mathrm{C}$ followed by $1 \mathrm{~min}$ at $94^{\circ} \mathrm{C}, 1 \mathrm{~min}$ at $35^{\circ} \mathrm{C}$ and $2 \mathrm{~min}$ at $72^{\circ} \mathrm{C}$ for 44 cycles and a final extension of $5 \mathrm{~min}$ at $72^{\circ} \mathrm{C}$, using a Trio-Thermoblock (BIOMETRA GmBH, Göttingen, Germany).DNA Alignment-The nucleotide sequences were aligned manually with Se-Al v1.0al (Sequence Alignment Editor Version 1.0 alpha 1; Andrew Rambaut, 1996).

The sequences obtained from this study were combined with other sequences deposited in GenBank and corresponding to Italian, French and Swiss populations; a sequence of $A$. torrentium from Genbank was also used as outgroup (AF237599; GRANDJEAN et al., 2000a).

Neighbour-Joining (NJ), and Maximum Parsimony (MP) methods were used for phylogenetic reconstructions. The $\mathrm{NJ}$ and MP and analyses were conducted on MEGA version 3.0 (KUMAR et al., 2004). MP trees were found by heuristic search using 
101 replicates of random stepwise addition. Bootstrap Percentages $\left(\mathrm{BP}_{\mathrm{MP}}\right)$ were computed after 1,000 replicates. The NJ tree was found using the "p" distance. The pairwise sequence divergence values among haplotypes were used to assess the mean sequence divergence between the two main clusters revealed in phylogeographic analyses.

\section{RESULTS}

All the analyses were based on a $301 \mathrm{bp}$ alignment of mitochondrial $16 \mathrm{~S}$ sequences. The sequences imported from GenBank were $199 \mathrm{bp}$ shorter than those of $500 \mathrm{bp}$ obtained in this study. The sequence alignments consisted of $301 \mathrm{pb}$ enclosing 62 variable sites, of which 26 are parsimony informative. Among Marches samples three distinct haplotypes M1, M2, M3 were detected (Table I). The geographical distribution of Marches' haplotypes is presented in Figure 1. Among these three haplotypes, M1 and M2 were closely related with a nucleotide distance, pi, between the two haplotypes of $0.6 \%$. These two haplotypes differ from M3 by a mean of $2.3 \%$. These haplotypes show a highly structured geographical pattern of distribution (Figure 1 and Table 1). Haplotype M1 was found in northern locations whereas haplotype M3 was found in southern locations. M2 was specific to one location: Rio Freddo. Two centrally located populations harbour both $\mathrm{M} 1$ and M3.

Both phylogenetic analyses from $\mathrm{NJ}$ and MP revealed the presence of two subspecies in hydrographic basins of Marches region: A. i. carsicus (M1 \& M2 haplotypes) that has been detected up to now only in the North-eastern Italy and in Alpi Orobie and $A$. $i$. meridionalis (M3) in the south. Two mixed populations with both subspecies $A$. i. carsicus and A. i. meridionalis were present in Amandole and Sanguerone from the hydrographic basin of Esino (the middle of Marches region) (Table I).

Pairwise mt16S sequence divergence was reported in Table II. The level of genetic variation within $A$. italicus subspecies is represented by the pairwise $p$-distance extimation (expressed as percentage) in Table II.

\section{DISCUSSION}

Our results showed that two subspecies overlap in Marches Region of Italy, A. $i$. carsicus and A. i. meridionalis. The distribution of $A$. $i$. carsicus in the central-northern part of the region was in accordance with the Italian ichthyogeographic Padan-Venetian (PV) district identified by BIANCO (1993). It could be explained by the extension of the Po River basin as far as the border of the meso-adriatic ditch, capturing water from a large number of rivers on both sides of the Adriatic Sea. In fact during glaciations the lowering of the sea level determined confluences of water between rivers flowing into the epicontinental area of the Mediterranean sea (CATTAUTO et al., 1988). A. i. meridionalis, recently described by FRATINI et al. (2005) from molecular data, and to the Apennine cluster defined by TRONTELJ et al., 2005 is located in Central-Southern Italy from both side of the Apennines chain. According to these authors, its presence in Slovenia could result from recolonization events from glacial refugial area during the Pleistocene due to the lowering of the sea level and the consequent confluence of some Adriatic rivers (BIANCO, 1995). In this study, we showed that its northern distribution reaches the central Marches Region where this subspecies is in contact with $A$. $i$. carsicus in the hydrographic basin of Esino. Two hypotheses could be drawn to explain the existence of mixed populations in central Marches region. They could be the result of a natural secondary contact between the two species during their spreading from different refugia after the last glacial period of the Pleistocene. According to the distribution of $A$. $i$. meridionalis, the refugial area during the last glaciation period could be located in the south of Italy, and from that area postglacial recolonisation events had taken place towards the north. Translocations by humans 


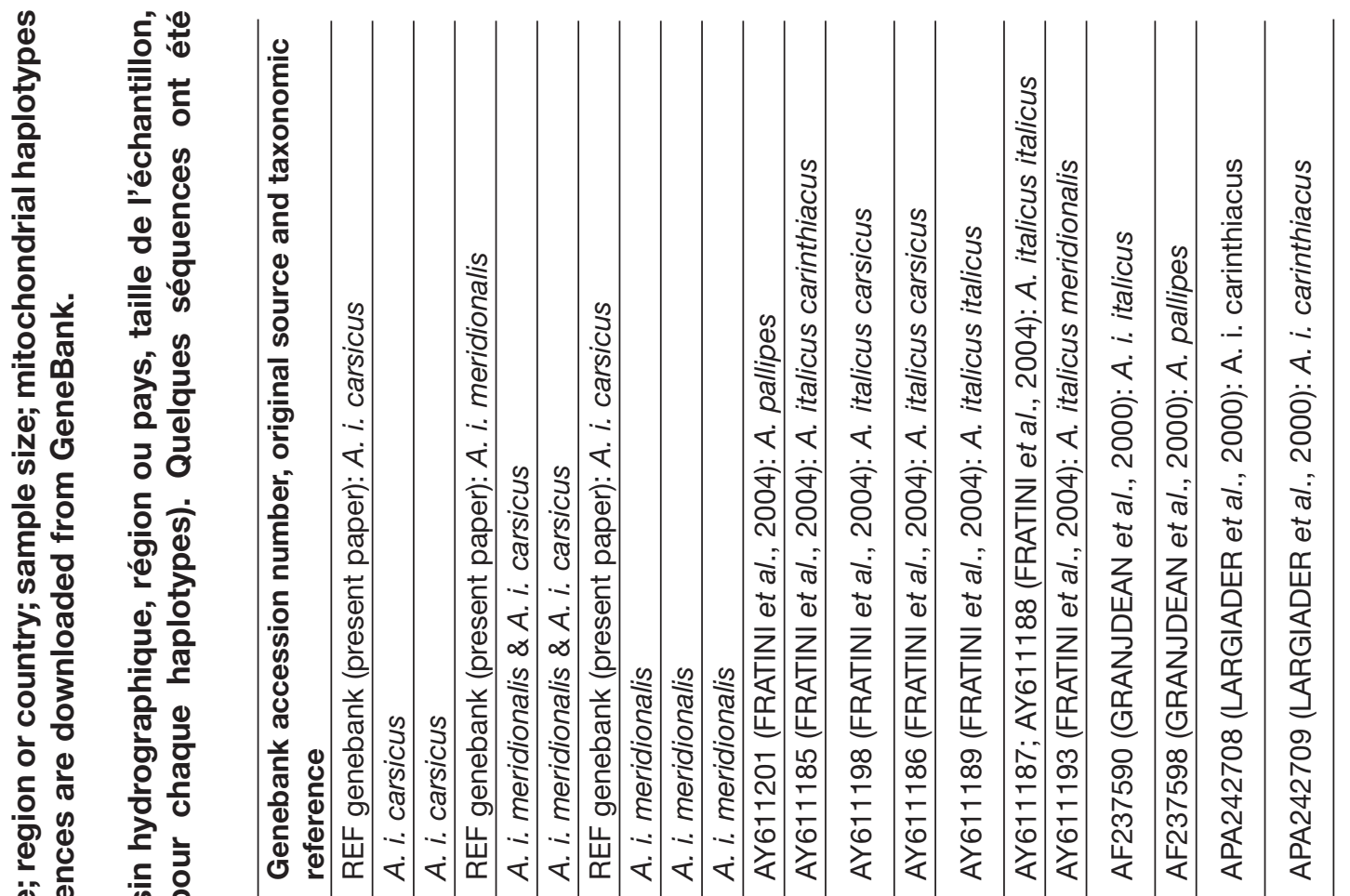

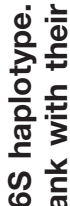

ภํำ

즌 $\stackrel{0}{\frac{0}{0}}$

능 인

등

일

के क

을

응 응

跑 \&

$\rightarrow$ iे

들ㅇㅇㅇ

ठ웡

ㅎํำ

흘 ํํํ

c

음 $\frac{\pi}{3} \frac{7}{5}$

के ब क्ष

खृ 융

- ब बิ

E

흔응 응

ㅎํㅇ क

ㅇํㅇ Ð

क्षे

흥 등

흉 ญ

을 응 ํㅡ

흘응 Ð் 응

도은

웡 잉

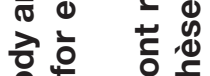

ㅇํㅇ 용

는 \&

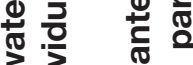

3.

范.

屯े

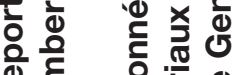

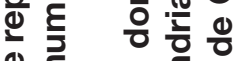

竞

刃ํ.

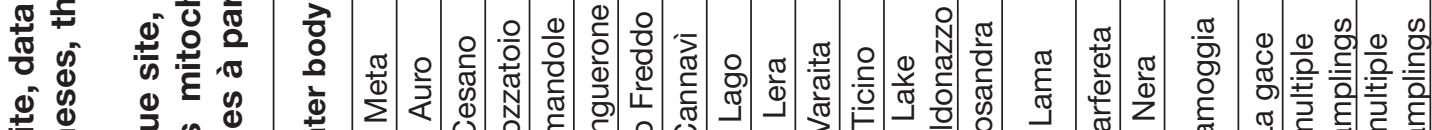

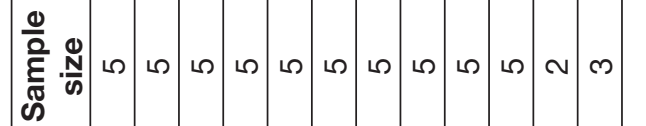

들

I

포 하잉

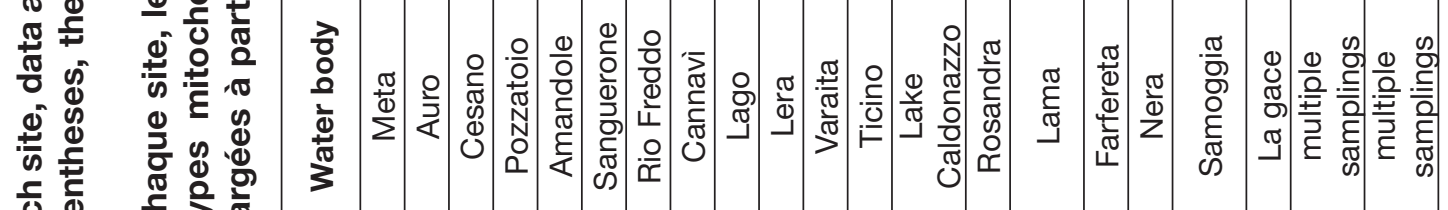

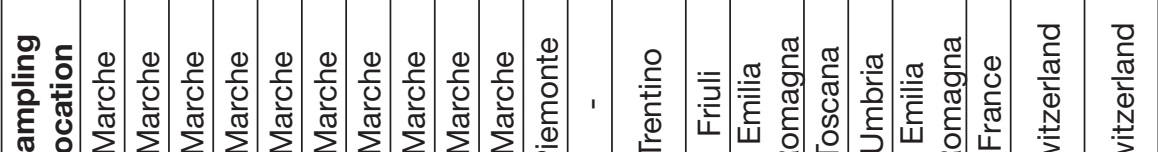

लू

$\frac{0}{\frac{2}{2}}$

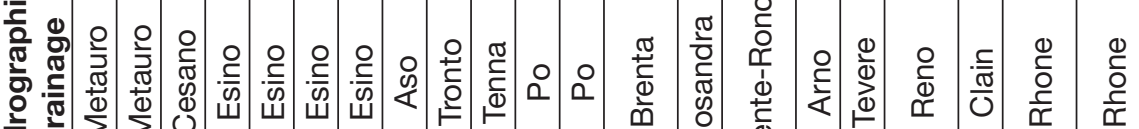
종

ญ 흉

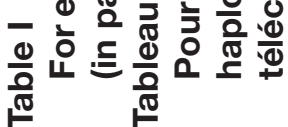

बึँ

뜬

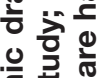

응 崩市

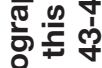

흥 흔 웡

능

온

동

증 응

응 응

¿

3는 훙

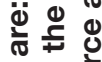

웡응

응 은.

똔

¿

홍울 을

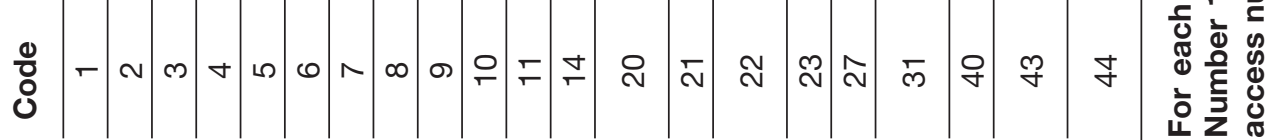




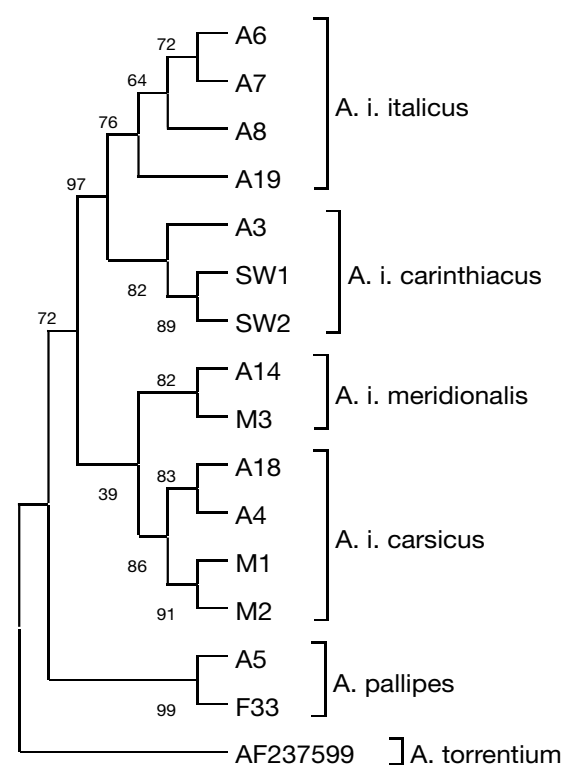

A

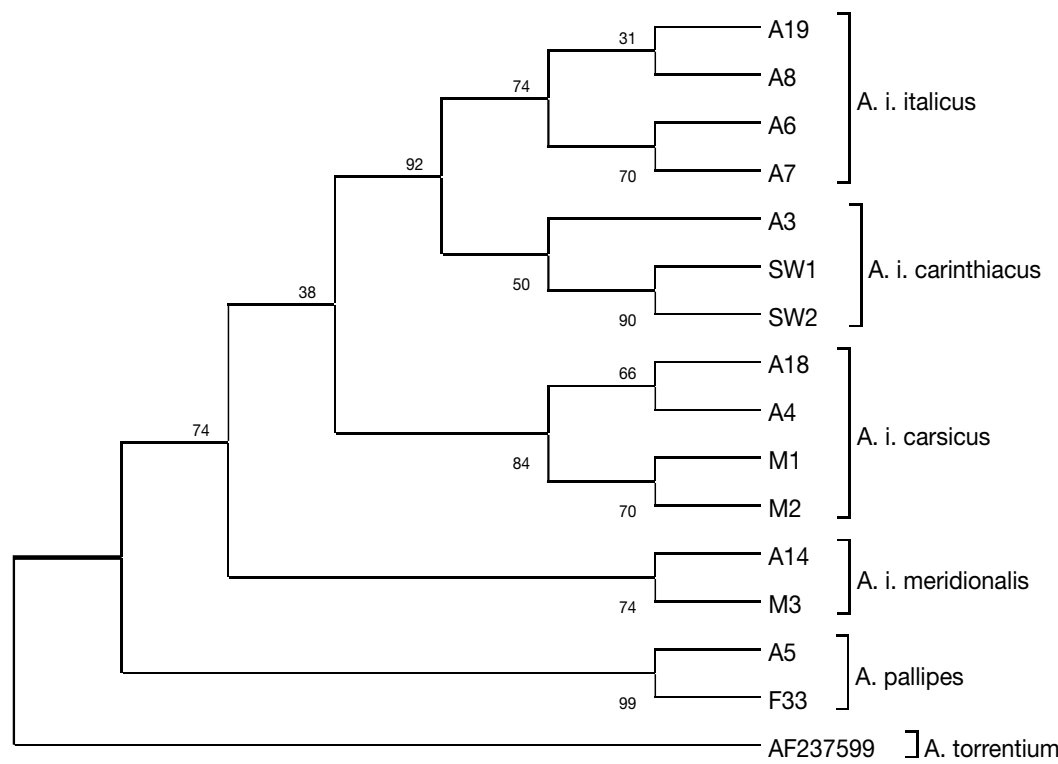

B

Figure 2

Molecular phylogeny of Austropotamobius spp. inferred by NJ (A) and MP (B) from $301 \mathrm{bp}$ fragment length of mtDNA $16 \mathrm{~S}$ gene. Bootstrap values are given above the nodes (1,000 replications). A. torrentium was used as out-group. The haplotype designations correspond to those reported in Table $\mathrm{I}$.

Figure 2

Phylogénie moléculaire d'Austropotamobius spp. établie par NJ (A) et MP (B) à partir de l'analyse de $301 \mathrm{bp}$ du gène codant pour L'ARN ribosomal 16S. Les valeurs de bootstrap sont portées au-dessus des nœuds (1 000 réplications). A. torrentium a été utilisé comme out-group. Les haplotypes cités correspondent à ceux reportés dans le tableau $\mathrm{I}$. 


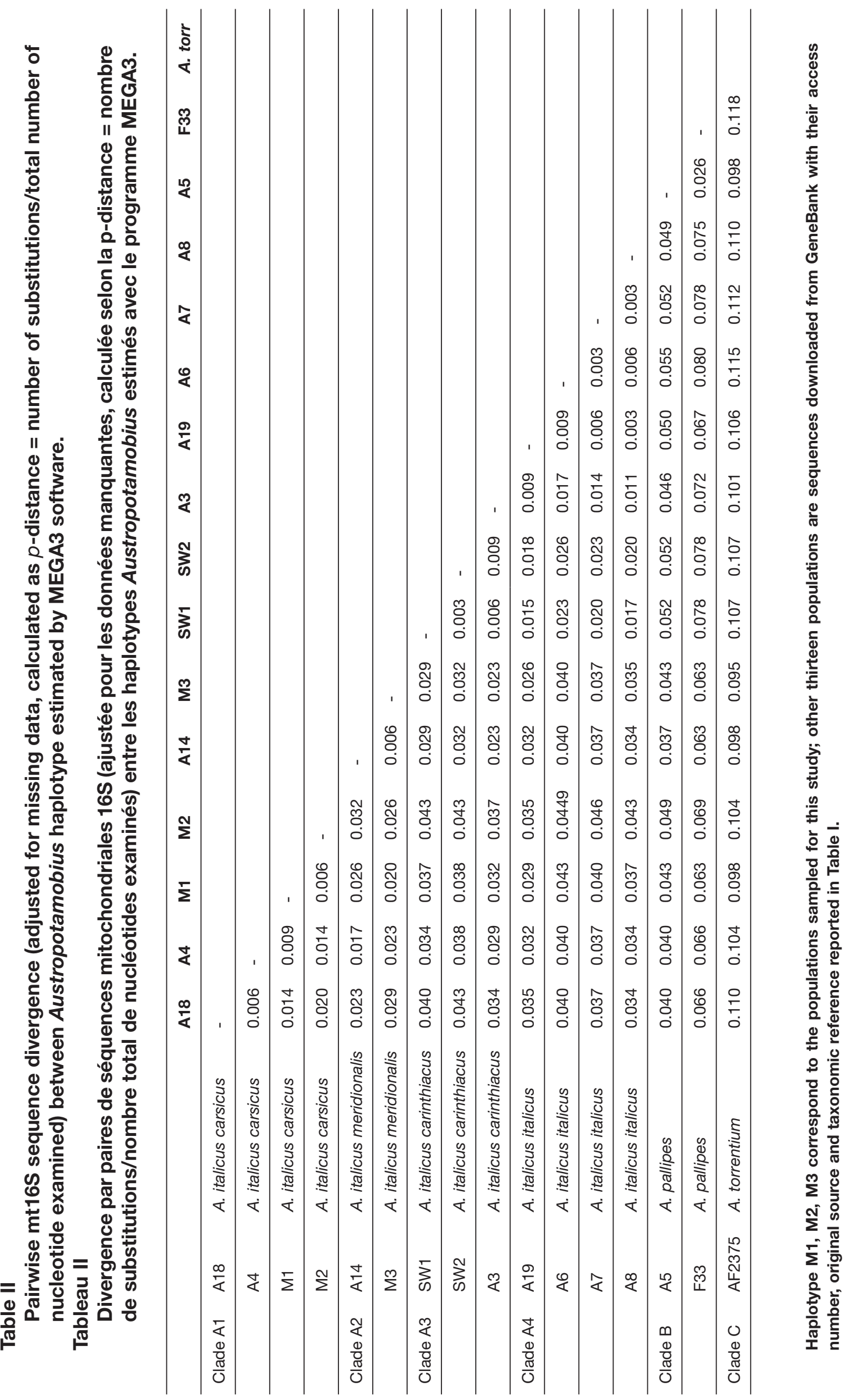


may also be the explanation for the presence of populations exhibiting both haplotypes in Amandole and Sanguerone. Humans have had a major impact on organism distribution by transporting animals, especially Crayfish, to many other geographical areas. According to LAURENT and SUSCILLON (1962), REYNOLDS (1998) and LARGIARDER et al. (2000), these practices occurred until recently on both the local and larger scales across Europe. The case of Spanish white-clawed crayfish is one of the best examples. Before the application of molecular markers, all authors ascribed a specific or subspecific status to Spanish crayfish, as either Austropotamobius lusitanicus or A. italicus lusitanicus. However, the molecular data provide a robust phylogeny which does not support this specific or subspecific status (GRANDJEAN et al., 2000 and 2002b, TRONTELJ et al., 2005). These authors explained the origin of the Spanish stock by a translocation of specimens from Italy. Also the analysis of nine Irish populations of Austropotamobius pallipes supported the evidence of the introduction in Ireland from western French specimens (GOUIN et al., 2001).

It was surprising to note that $A$. $i$. italicus while present in the northern and northeastern Marches border regions, Emilia Romagna and Tuscany, does not appear in Marches region (FRATINI et al., 2005). This could be explained by restricted gene flow between the Adriatic and Mediterranean sides of the Apennine chain.

\section{CONCLUSIONS}

Our study confirmed that the application of molecular markers is a prerequisite before considering a management program, in helping taxonomic decisions, especially at specific and intraspecific levels where taxonomic recognition is based on limited numbers of morphological traits. The lack of a precise knowledge of genetic structure could have resulted in establishing populations of allochthonous taxa, and in the genetic contamination of local populations contrary to good conservation management. In terms of conservation genetics, two separated ESU (Evolutionary Significant Units according to Moritz's definition, 1994) occur in Marches. Each should be given conservation priorities and should be managed separately. However, one advantage of such mixed populations is the opportunity to test reproductive isolation between these lineages by the use of nuclear markers.

The next step of this work will be to investigate the genetic variability within populations with more polymorphic mtDNA gene or molecular markers in relation to the hydrographic basins, to improve our knowledge of these populations with the aim to plan conservation projects including restocking and restoration operations in this region. Given the taxonomic unit differences between Emilia Romagna and Marches regions, it would be interesting to verify the probable presence of $A$. $i$. carsicus in Emilia Romagna, too.

\section{ACKNOWLEDGEMENTS}

We are grateful to Prof. ssa Maria Balsamo for her skilful scientific and organisational support. A fundamental role, for their technical assistance in sample collection, was played by Patricia Viviana Masini and Maurizio Fusari. Many thanks for their support to the Ente Parco Nazionale dei Monti Sibillini and to the Amministrazioni Provinciali of Pesaro e Urbino, Ancona, Macerata, Ascoli Piceno.

\section{REFERENCES}

BIANCO P.G., 1993. L'Ittiofauna continentale dell'Appennino umbro-marchigiano, barriera semipermeabile allo scambio di componenti primarie tra gli opposti versanti dell'Italia centrale. Biogeographia, vol. XVII, 427-485. 
BIANCO P.G., 1995. Mediterranean endemic freshwater fishes in Italy. Biological Conservation, 72, 159-170.

CATTAUTO C., CENCETTI C. and GREGORI L., 1988. Lo studio dei corsi minori dell'Italia Appenninica come mezzo di indagine sulla tettonica del Plio/Pleistocene. Boll. Mus. St. Nat. Lunigiana, 6-7, 7-10.

FRATINI S., ZACCARA S, BARBARESI S., GRANDJEAN F., SOUTY-GROSSET C., CROSA G., GHERARDI F., 2005. Phylogeography of the threatened crayfish (genus Austropotamobius) in Italy, implications for its taxonomy and conservation. Heredity, 94, 108-118.

FÜREDER L., OBERKOFLER B., HANEL R., LEITER J., THALER B., 2003. The freshwater crayfish Austropotamobius pallipes in South Tyrol, Heritage species and bioindicator. Bull. Fr. Pêche Piscic., 370-371, 79-95.

GOUIN N., GRANDJEAN F., BOUCHON D., REYNOLDS J.D., SOUTY-GROSSET C., 2001. Population genetic structure of the endangered freshwater crayfish Austropotamobius pallipes, assessed using RAPD markers. Heredity, 87, 80-87.

GRANDJEAN F. and SOUTY-GROSSET C., 2000. Mithocondrial DNA variation and population genetic structure of the white-clawed crayfish Austropotamobius pallipes pallipes. Conservation genetics, 1, 309-319.

GRANDJEAN F., HARRIS D.J., SOUTY-GROSSET C., CRANDALL K.A., 2000. Systematics of the European endangered crayfish species Austropotamobius pallipes (Decapoda, Astacidae). Journal of Crustacean Biology, 20(3), 522-529.

GRANDJEAN F., BOUCHON D., REYNOLDS J.D., SOUTY-GROSSET C., 2002a. Systematic of the European endangered crayfish species Austropotamobius pallipes (Decapoda, Astacidae) wiyh a re-examination of the status of Austropotamobius berndhauseri. J. Crust. Biol., 22, 677-681

GRANDJEAN F., FRELON-RAIMOND M., SOUTY-GROSSET C., 2002b. Compilation of molecular data for the phylogeny of the genus Austropotamobius, one specie or several Bull. Fr. Pêche Piscic., 367, 671-680.

HOLDICH D.M., 2002. Distribution of crayfish in Europe and some adjoining countries. Bull. Fr. Pêche Piscic., 367, 611-650.

KUMAR S., TAMURA K., and NEI M., 2004. MEGA3: Integrated software for Molecular Evolutionary Genetics Analysis and sequence alignment. Briefings in Bioinformatics, 5:150-163.

LARGIADER C.R., HERGER F., LÖRTSCHER M., SCHOLL A., 2000. Assessment of natural and artificial propagation of the white-clawed crayfish (Austropotamobius pallipes species complex) in the Alpine region with nuclear and mithocondrial markers. Molecular Ecology, 9, 25-37.

LAURENT P.J., SUSCILLON M., 1962. Les écrevissses en France. Annales de la Station Centrale d'Hydrobiologie, 9, 336-395.

LÖRTSCHER M., CLALÜNA M., SCHOLL A., 1998. Genetic population structure of Austropotamobius pallipes (Lereboullet 1858) (Decapoda, Astacidae) in Switzerland, based on allozyme data. Aquat. Sci., 60, 118-129.

MORITZ C., 1994. Defining' evolutionary significant units' for conservation. Trend Ecol. Evol., 9, 373-375.

REYNOLDS J.D., 1998. Ireland's freshwaters. Marine Institute, Dublin. 
SANTUCCI F., IACONELLI M., ANDREANI P., CIANCHI R., NASCETTI G., BULLINI L., 1997. Allozyme diversity of European freshwater crayfish of the genus Austropotamobius. Bull. Fr. Pêche Piscic., 347, 663-676.

TRONTELJ P., MACHINO Y., SKET B., 2005. Phylogenetic and phylogeographic relationships in the crayfish genus Austropotamobius inferred from mitochondrial COI gene sequences. Mol. Phyl. Evol., 34(1), 212-226.

ZACCARA S., STEFANI S., GALLI P., NARDI P.A., CROSA G., 2004. Taxonomic implications in conservation management of white-clawed crayfish (Austropotamobius pallipes) (Astacidae, Decapoda) in Northern Italy. Biological Conservation, 120, 1-10.

ZACCARA S., STEFANI S., CROSA G., 2005. Diversity of mitochondrial DNA of the endangered white-calawed crayfish Austropotamobius italicus in the Po River catchment. Freshwater Biology, 50, 1262-1272. 